\title{
Haader Lea A Magyar Nyelv Történeti Nyelvtana Brassai Sámuel Tanításának Szemszögéből
}

\begin{abstract}
„A nyelvész Brassai élő öröksége” - a konferencia címe arra ösztönzi a résztvevőt, hogy a nyelvtudomány különféle ágaiban folyó munkákat - ki-ki a saját szakterületé - szembesítse Brassainak a múlt század második felében papírra vetett a nyelvröl szóló nézeteivel. Mivel az utóbbi évek nyelvtudományi terméséhez tartozik az 1991 és 1995 között megjelent a magyar nyelv történeti nyelvtana (a továbbiakban TNyt.) is, illendő, hogy ezt is néhány lényegesebb szempontból megnézzük a Brassai-tükörben. A tükörbe nézés müvelete persze nem tünik egészen kockázatmentesnek, hiszen közismert hogy Brassai nem sokra becsülte a történeti nyelvészetet, és minden alkalmat megragadott, hogy megsemmisítő véleményét minél hatásosabb módon ki is fejtse. A történeti szempontok teljes elhanyagolása ugyanakkor egyes részletek megítélésében tévutakra is vezette, mint pl. A tárgyrag és a locativusi $t$ egyezésének hangoztatásában, de több más esetben is. Az elmúlt száz év azonban nem múlt el nyomtalanul a történeti nyelvészet felett sem, az a történeti nyelvészet nem ez a történeti nyelvészet, $s$ erősen reméljük, hogy Brassai a TNyt. Alapelveit, módszerét látva nem írna ma már annyi lesújtót terjedelmes, csillaggal jelölt lábjegyzeteiben. Álljunk hát a tükör elé, szembesítsünk célkitüzést, módszert, vizsgálati anyagot, szemléletet, mondattani elveket!
\end{abstract}

Előadásomat három főbb kérdés köré csoportosítottam: 1. általános kérdések; 2. dualizmus, alany-állítmány viszony; 3 . vonzatosság, tekintettel a mellékmondatos vonzatosságra.

Következzenek hát az általános kérdések!

1. Brassai így kezdi a magyar mondatról szóló értekezésének I. fejezetét: „,... a nyelv e g y má s m e 11 e t t é s e g y má s u tá n létező megállapított tények sora és halmaza; oly tényeké, melyeket egyéniségökben és kapcsolatukban, müködésökben és irányukban felfoghatni, vizsgálhatni, érzékelhetni, h a s o n 1 ít h a t n i é s k ü 1 ö n b ö z t e t h e t n i,"57 ( a kiemelés tỏlem - H.L.). Nos: a TNyt. egy ennek megfelelő feldolgozási módot választott, mégpedig: egy-egy nyelvtörténeti korszak szinkrón jellegü leírását adja [ez az e g y m á s m e 11 e $\mathrm{t}$ t], majd az egyes korszakok egymásra vetítésével szándékozik a $\mathrm{n}$ y e $1 \mathrm{v}$ i rendszer elemeinek elmozdulásait feltérképezni [ez az e g y má s u tá n]. A történeti vizsgálatának effajta felfogása merőben más, mint az ezt megelőző történeti nyelvtanok koncepciója volt. Azokról az mondható el, hogy többnyire elemtörténetet adtak, tehát úgymond ,etimológiai természetüek" voltak, makrodiakrónikusak, a nyelvet felülnézetből szemlélték. ${ }^{58}$ a TNyt. Amikor a történeti szinkrón metszetek készítése mellett döntött, másfajta (a korabeli nyelvet alaposabban, korszerübben vizsgáló és láttató) útra szánta el magát. A történeti szinkrónia fogalma természetesen nem fedi, nem fedheti a szinkrónia leíró fogalmát, egy-egy metszet nem harminc-negyven, hanem két-háromszáz évet is átfoghat.

Mi kell egy megközelítően hiteles szinkrón történeti állapotrajz elkészítéséhez? a feldolgozható legnagyobb korpusz, mégpedig azért, hogy megvallatása által érzékeltetni lehessen a nyelv egykor volt életét, az elemek mozgását, az egymással konkurens elemek

\footnotetext{
${ }^{57}$ a magyar mondat. In: Magyar Akadémiai Értesítő I, 284-5.

${ }^{58}$ Vö. Károly Sándor: NytudÉrt. 104. sz. 48
} 
harcát, megjelenést, gyakorivá válást, vagy éppen megritkulást, eltünést. ${ }^{59}$ (Hogy is mondja Brassai?: „egyéniségökben és kapcsolatukban, müködésükben és irányukban”.)

Az effajta leíráshoz szükséges módszer nem is lehet más, mint az indukció (kár, hogy ez olykor - talán nem szándéktalanul - taxonómiává degradáltatik).

Következik a vizsgálandó anyag problémája. Brassai hangsúlyozza, hogy a mondattani kutatásokban az élőbeszéd által nyújtott anyagból kell kiindulni: „,csak élő szóval ejtett mondatokból meríthetni ... az élőszóejtés ... a magyar mondat egész alkatában és mindenütt szabályzó hatalom" - írja. ${ }^{60}$ Ez olyan kívánalom, amelyet egy történeti nyelvészeti vizsgálat természetesen nem tud teljesíteni. A történeti nyelvtanírás legnehezebb problémái, legkényesebb módszertani kérdései sürüsödnek itt a vizsgálandó anyag számunkra ugyanis egy í r á s b a n f e n n m a r a d t ún. zárt korpusz, amelynek mondatait (vagy mondjuk így: írásbeli nyilatkozatait) a teljesen nyilvánvaló hibáktól eltekintve grammatikálisnak kell elfogadnunk. A hibák jó része egyébként a kései ómagyar kori szövegek latinból fordított mivoltának számlájára írható. De ez a nehézségeknek csak az egyik oldala. A másik - nem kevésbé súlyos - bökkenö, hogy ennek a régi nyelvnek (az ómagyar kor tekintetében csupa területi nyelvváltozatnak) a nyelvtaníró nem (lehet) kompetens beszélöje. A megítéléseknek tehát rendkívül óvatosnak kell lenniük, még akkor is, ha többé-kevésbé sikerül kialakítani a vizsgálathoz elengedhetetlen ún. pótkompetenciát. ${ }^{61} \mathrm{~A}$ föparancs mindenesetre az, hogy tilos mai nyelvi kompetencia alapján megítélni az egykor volt nyelvi jelenségeket.

Nincs tehát élőszóval ejtett mondat, nincs valódi kompetencia, a TNyt. mégis - Brassai szellemében és kívánalmainak megfelelően - vizsgálja pl. Az ómagyar kori mondatok szórendjét, és - ami ennél még jelentősebb, de egyben kritikusabb is - aktuális tagolását. Megjegyzendő, hogy ez utóbbi először fordul elö történeti grammatikában. Mik lehetnek hát itt a módszertani fogódzók, hogyan lehet egy ötszáz évvel ezelött leírt mondatot hangsúllyal, intonációval megtölteni, azaz „hangosítani”? Elekfi László nagyjából hasonló feltételek mellett vizsgálta Petőfi versmondatainak aktuális tagolását. Ezt írja: „A mondatnak mint beszédegységnek meghatározott akusztikai lefolyása, hallható formája, intonációja van. ... a leírt mondat valójában éppúgy nem mondat, ahogy a szonáta kottája nem azonos magával a szonátával. A vers írott 》mondatai《 azonban legtöbbször nem állnak elszigetelten. A szavak és a mondatok rendje, a szavak jelentése ... determinálja ... az intonációs sajátságokat. ... Egy írott mondat persze sokféle változatban intonálható, ezek azonban legtöbbször csak érzelmi színezés tekintetében különböznek egymástól. Értelmileg különböző változatok csak ritkábban engedhetők meg egy-egy poliszemantikus hely interpretálásában vagy mellékesebb, kevésbé lényeges értelmi árnyalatok kifejezésében." ${ }^{\circ 2}$ Ez tehát az a módszertani fogódzó, amelyre támaszkodva vállalhatta Wacha Balázs, a TNyt. Aktuális tagolás fejezeteiben a korai és kései ómagyar korról tett megállapításait. Érdekes, hogy a nyelvtan egyik bírálója éppen tudományos korrektségét, elbizonytalanított megállapításait rója fel neki (megokolva a valódi nyelvi kompetencia fent említett és szükségszerü hiányával). ${ }^{63} \mathrm{~S}$ ugyanezért nem vállalta Károly Sándor a szövegtani részben a téma-réma tagolás vizsgálatát. ${ }^{64}$

„A nyelvbeli egyén: a mondat” - írja Brassai. ${ }^{65}$ Ez az egyén „határozott alakú egész; mely maga nem szükségképi része semminek, de a melynek részei reá nézve szükségképiek." ${ }^{66}$

\footnotetext{
${ }^{59}$ Vö. Károly: NytudÉrt. 104. sz. 49

${ }^{60}$ a magyar mondat. Magyar Akadémiai Értesítő III: 279.

${ }^{61}$ Vö. Forgács Tamás: NéprNytud. 35: 19-23

${ }^{62}$ Elekfi László, Petöfi verseinek mondattani és formai felépitése 20. Bp., 1986

${ }^{63}$ Forgács Tamás: MNy. 92:389

${ }^{64}$ TNyt. II/2: 764

${ }^{65}$ AkÉrt. I: 299

${ }^{66}$ AkÉrt. I: 302
} 
Hogy egy mondattan a mondatot teszi meg alapegységének $\mathrm{s}$ ahhoz képest viszonyít nagyobb és kisebb egységek felé, ez magától értetődő. Újabban azonban szokás a nyelvbeli egyént a másik oldalról, a szöveg oldaláról is megközelíteni (neve ilyenkor szövegmondat, nyilatkozat). Brassai szerint viszont „,mondatokból csoportosulhat ugyan egy felsőbb nemü egyén, éppen úgy, mint fákból erdő, mint juhokból nyáj, vagy, mint házakból helység, de ez a csoportosulás nem szükségképi, magában nem nélkülözhetetlen."67 a nyelvbeli egyén szövegépítő szerepét, s ennek az építkezésnek a grammatikai következményeit a TNyt.-i koncepció hangsúlyosan fontosnak ítélte, így egészült ki a nyelvtan a szöveggrammatikai fejezettel.

2. A szembesítés következő résztvevői: a mondat dualizmusa és az alany-állítmányi viszony. Brassai kereken kimondja: a mondatban nincs dualizmus; dualizmuson azt értve, hogy „minden mondatnak alkatszerüleg két részből, ú.m. subjectumból és praedictumból kellene állani”,68

Később finomít a megfogalmazáson: „Nem úgy értve mindazáltal, hogy egy mondatban sem volna dualizmus, de bizony van akárhányban, hanem csak úgy, hogy a dualizmus nem tartozik a mondat fogalmának lényeges jegyei közé." ${ }^{69}$ Még később viszont a saját - más szempont - dualizmusának szinte bajnokává válik. Természetesen a mondat definíciójába már régóta nem tartozik bele a kéttagúság. (Erről Berrár Jolán írt igen alaposan az Ányt. I. Kötetében.) ugyancsak Berrár Jolán az, aki az Alany és állítmány címü cikkében ${ }^{70}$ részletesen elemzi az egyfőtagú (monorém) mondatokat, föbb típusaikat is megállapítva. $\mathrm{S}$ talán már most érdemes előhozakodni azzal, hogy ugyancsak ő az, aki az alanyt és az állítmányt érintő terminológiai kérdésekben is véglegesen rendet teremt, következetesen szétválasztva a lélektani és grammatikai alany-állítmány fogalmakat, $\mathrm{s}$ fontosságuk fenntartása mellett mindegyiket a megfelelö helyre utalva. Brassai többször beszél róla, hogy a grammatikai alany nem felel meg a beszédbelinek, hogy a „subjectum bevett értelmezése nem képesít a subjectum kitalálására", ${ }^{71}$ míg odáig jut, hogy magát a subjectum szót feleslegesnek tartva a vele jelölt fogalmat másként nevezi el. ${ }^{72}$ a már ismert rész és az új közlés szembeállítására (amelynek legfőbb kifejezőeszköze a hangsúly és a szórend) okvetlenül más elnevezést kell keresni - figyelmeztet Berrár. Majd így folytatja: „Válogathatunk a Brassai-féle inchoativum és mondatzöm, az újabb téma és réma, az angol szaknyelvből topic és comment elnevezéspárok között, kereshetünk új magyar neveket, csak éppen alanynak és állítmánynak nem hívhatjuk őket" ${ }^{73}$ Berrár a mondattan igen lényeges fejezetének tartja a kommunikáció szempontjából döntő aktuális tagolást, de szigorúan elválasztja az alany és állítmány kérdéskörétől. A TNyt. - mint már a korábban mondottakból részben világossá válhatott (Brassai kívánalmainak megfelelően) ugyanezt a koncepciót követi. Fontos új fejezetként beiktatja az aktuális tagolás vizsgálatát, terminológiailag és minden szempontból elválasztva azt az alany-állítmányi viszony kérdéskörétől. Ami ez utóbbit illeti, megítélése Brassainál és újabban minden nyelvtanban összefügg a mondatfelépítésről, az ige szerepéről vallott felfogással. Vonzat-e az alany? - ez a központi kérdés. Brassai válasza egyértelmünek tűnik: a mondatban az uralkodó középpont az ige, s ez vonzza az alanyt, tárgyat, határozókat, amelyek között azonban szintaktikai tekintetben semmi különbség sincs, egyik se lényegesebb vagy

\footnotetext{
${ }^{67}$ AkÉrt. I: 303-304

${ }^{68}$ AkÉrt. I: 325.

${ }^{69}$ AkÉrt. I: 331-2.

70 Tanulmányok a mai magyar nyelv mondattana köréböl 79-93. Bp., 1977.

71 AkÉrt. I: 329.

${ }^{72}$ Vö: AkÉrt. I:341.

73 TanMondt 81.
} 
nélkülözhetetlenebb, mint a másik. ${ }^{74}$ Máshol azonban már némi „rangfokozatot” ad az egyes alattvalóknak. $^{75}$

Ismeretes, hogy a nyelvtani szakirodalomban az alany és állítmány viszonyának kérdése régóta neuralgikus pont. E viszony (vagy éppen nem viszony) megítélésére ötfajta válasz is született, közülük ma kettő számít kurrensnek. Legerősebb képviselete az állítmány primátusát vallónak, amely a Brassai kezdeményezte igeközpontú szemléleten alapszik. A modern nyelvtanok közül ennek a felfogásnak a jegyében áll a Strukturális Nyelvtan, de harcos képviselöje Deme László is. Érdekes azonban, hogy Brassai és Deme kiindulópontja bár a végeredmény tekintetében erősen hasonló véleményen vannak - egészen más. Brassai az ige elsőbbségének kialakulását annak dinamizmusával magyarázza, azzal, hogy „figyelmünket elébb és sokkal erélyesebben ébreszti a mozgó, élö, ható mint a nyugvó, a holt a hatástalan." "76 Ennek illusztrálására hozza fel ismert történetét a „nyelvalkotó korban” a természet mély csendjében egymással szemközt ülö két emberröl. Egy madár felröppenését akarja közölni egyik a másikkal, öt azonban elérni nem tudván „egy röffenés, dunnogás, csemcsegés, szisszenés, vagy plattyogtatás épen azt a szolgálatot teszi”. ${ }^{77}$ Íme, így jött létre a fejedelmi szófaj, az ige, melynek vazallusai, az egyéb szófajok csak ezután fejlődnek ki. Deme kiindulása egészen más. ő kezdeti egyenrangúságból, kétsarkúságból indul ki, s az állítmány (nem az ige) központi maggá válását a mondat tovább osztódásával magyarázza. Ennek a folyamatnak a során értékelődik aztán át az alany a bővítmények egyik típusává. Azért Deme is megjegyzi azt, hogy az alany-állítmány viszonyban az aláfölérendeltség ma sem olyan tiszta és kétségtelen, mint a többi mondatrész és az állítmány viszonyában. ${ }^{78}$ (Ez emlékeztet kissé Brassai rangfokozataira.)

A másik, a hozzárendelés-felfogás strukturális érveken alapszik. Elég itt csak emlékeztetni a Berrár által többször elemzett $\mathrm{a}+\mathrm{b}=\mathrm{c}$ képletnek megfelelö szintaktikai szerkezetre (az ismert kritériumok szerint: disztribúció, behelyettesíthetőség, kérdezhetőség, kihagyhatóság, mellékmondattal való kifejezhetőség). ${ }^{79}$ Ez utóbbi semmiképpen sem elhanyagolható szempont. Mellékmondattal ugyanis egy szintaktikai viszonyból az alárendelt tag fejezhetö ki. (Hallom kopogását.-Hallom, hogy kopog.) Az alany-állítmányi szerkezetből (ha az állítmány névszói) mindkét tag viselkedéséről Brassai is említést tesz, amikor azt írja: ,a tulajdonítmányos logikai ítéletek képeit viselik." ${ }^{~} 0$

A kétféle felfogásmódot Károly Sándor kísérli meg összehangolni: ,az igének és alanyának, mint a mondat két fő tagjának rangsorát illetően nem szabad figyelmen kívül hagyni, hogy ez a szerkezet legalább két síkon értékelendő ki: szerkezetes felépítése szempontjából, a konnexió szempontjából egyenrangúnak tartom a kettőt. A beszédbeli sík szempontjából az igét tartom fontosabb, domináns tagnak. Ha elválasztanám a szintaxist a mondattantól, akkor a szintaxisban egyenrangú felekként tekinteném őket, mint két konzult, a mondattanban, ahol a modalitás kérdései kerülnének elő a mondatfajták kérdéseivel együtt, az igének adnám a császárságot." 81

Ezek után éppen itt az ideje, hogy megnézzük, milyen felfogást követ a TNyt. ebben a fontos kérdésben: Brassai elvei hatnak-e, vagy másfajta elvek. Talán úgy fogalmazhatnánk, hogy a nyelvtan lutheránus megoldást választott. Hozzárendelő szerkezet címen tárgyalja az alanyállítmányi szerkezetet, ugyanakkor a mondatot felépítő szerkezetek vizsgálatában szófajköz-

\footnotetext{
${ }^{74}$ Vö: Paraleipomena kai diortoumena 5-6. Bp., 1873.

${ }^{75}$ Vö: AkÉrt. I: 332.

${ }^{77}$ Uo.

${ }^{78}$ Mondatszerkezeti sajátságok gyakorisági vizsgálata 46. Bp., 1971

${ }^{79}$ Vö.NytudÉrt. 46. sz. 17-24.

${ }^{80}$ AkÉrt. III: 240

${ }^{81}$ ÁNyT. 1:177.
} 
pontú, és az alanyt az ige bővítményei között is szerepelteti. Brassai számára ez biztosan megérne egy jegyzetet.

Kissé más szemmel kell néznünk az alany és az állítmány már fentebb említett mellékmondatos kifejeződését. Tetszik, nem tetszik, az ómagyar kori zárt korpuszban szép számmal fordulnak elő névszói állítmányt kifejtő, a főmondatbeli a 1 a n y t azonosító állítmányi mellékmondatok. Ilyen esetben a kölcsönösség tünik megfelelő viszonynak. Brassai mondatmodelljében egyébként sem jut sok hely az összetett mondatoknak, amelyeket ö periódusnak nevez. E területen hát szerényebb az örökség.

3. A harmadik kérdéskör - amely az előzőtől semmiképpen sem független - a vonzatosságé. A híres igehasonlatból szinte következhetne a valenciaelmélet, a vonzatosság mai típusú felfogása. Brassai azonban nem szereti a “vonzat' kifejezést. „Csodálkozom nyelvtanárainkon, - írja - a kik behozták s a kik elfogadták.” Ez ugyanis a reglementet s a kötéllel fogott katonát juttatja az eszünkbe. „Magam is monarchának ismertem el az igét a mondatban, de alkotmányosnak, aki uralkodik, de nem kormányoz'; s a mondat többi részeit szabad alattvalóknak, kik a törvénynek s nem a nyers hatalomnak hódolva teljesítik kötelességöket." ${ }^{82}$ a határozók közötti egyenlöségben nincsen igaza Brassainak, mert a különféle bővítmények különféle erősséggel kapcsolódnak uralkodójukhoz, vegyük csak pl. A minimális szerkesztettségü mondat fogalmát. Még elvetendőbbnek tartja Brassai, hogy egyes nyelvtanok még a föneveknek is tulajdonítanak vonzóerőt. Egészen tudománytalannak minősíti „,a határozók értelmeit, és viszonyait egyoldalúan az ige cselekvénye minőségétől függeszteni fel." ${ }^{, 3}$ a viszonyokat a képzők [!] és a ragok fejezik ki, ha pedig „a cselekvénytől függenek, az igét magát ragozza a nyelv (látom, hallom). ${ }^{, 84}$ Ezzel tkp. Az igei alárendelő szerkezeteken belüli viszonyítás és egyeztetés elkülönülését mondja ki, amelynek azonban - azonkívül, hogy a tárgy mindig kötött bővítmény - nem nagy a jelentősége a vonzatosságban. Láthatóan elveti hát a mai vonzatfelfogást. Biztosan az ellen is tiltakozna Brassai, hogy a mondatbeli vonzatrelációk feltárása nem a vonzatszerepet betöltő egységeknek, hanem a szerepet meghatározó régensnek a megismerését igényli, ${ }^{85}$ - pedig hát igenis a szótári tétel joga, hogy akár mint nap mely bolygókat, akár mint uralkodó mely alattvalókat lát szívesebben, enged közel magához.

A TNyt. is a vonzatosság figyelembevételével építkezett. Szófajonként vizsgálja a vonzatosságot: elsőként az ige szerkezeteiben, majd - Brassai szándékaival nem egyezően - a főnévében, melléknévében, számnévében, határozószóéban; - mindig megkülönböztetve a szabad szerkesztésmódtól. A módszertani nehézségekre azonban itt megint utalnom kell. Ha valahol, hát itt szükség volt a pótkompetenciára. Komlósy András egyenesen azt írja a Strukturális nyelvtanban, hogy „,egy nyelv bármely mondatának bármely bővítményéröl csak az tudhatja eldönteni, hogy az vonzat-e vagy sem, aki az adott nyelv egészét birtokolja." 86 Azért mégis reménykedünk, hogy nem mindent döntöttünk el rosszul.

A mellékmondattal kifejezett bővítmények kérdésköre némileg más megközelítést kíván (az alannyal és az állítmánnyal kapcsolatban is volt már erről szó). Ezekben az esetekben a régens és a mellékmondati bővítmény együttese olyan vizsgálati szempontokat is felvet(het), amelyek a mondatrésszel kifejezett argumentumokkal kapcsolatban nem relevánsak. Itt ugyanis ha nincs a főmondatban utalószó - hiányzik a vonzatnak az a kitevője, amelynek alapján a vonzatstruktúrát meg lehet határozni. Ez elég gyakori eset a középkori szövegekben. A

\footnotetext{
${ }^{82}$ AkÉrt. III: 288.

${ }^{83}$ AkÉrt. III: 252.

${ }^{84}$ Uo.

${ }^{85}$ Strukturális magyar nyelvtan I. 314. Bp., 1922.

${ }^{86}$ Uo.
} 
jelenség oka lehet, hogy már a mellékmondatnak a puszta léte jelzi azt, hogy az alaptagrégens közelebbi alattvalót kíván maga mellé. Másrészt ezek többnyire ún. tartalomkifejezést elváró régensek (lehet, illik, tetszik stb.), amelyeknek vonzata kizárólag vagy túlnyomó többségben csupán mellékmondattal fejeződhet ki.

Az ómagyar kori mellékmondatok körében a fentiek figyelembevételével az alábbi csoportokat vehetjük fel: kötött bővítményt kifejtők (tárgyiak és kötött határozóiak - csupán a struktúra kötöttsége szerint, azaz aszemantikusak és szemantikusak egyaránt), valamint szabad bővítményt kifejtők. Ebben a csoportban Brassai által nyilván nem szívesen látott (mert szerinte sehova se vezetö) mondatrészi felosztás az alap (mindig megfigyelve, hogy ki a fömondatnak nem régens, hanem békés monarchiája; ez azonban nem mindig igei szófajú). Itt kénytelenek vagyunk a mellékmondatos szerkesztésben jellemző, fontos szerepet játszó kötőszó szempontjaira is tekintettel lenni. Ezt a legspeciálisabb helyzetet a helyhatározói mellékmondatokkal kapcsolatban idézi elö. Nagy részük ugyanis mondatrészként tiszta vonzat lenne, kötőszavuk azonban sohasem hogy, ${ }^{87} \mathrm{~s}$ ezért sorolódtak be magyarázó megjegyzések kíséretében a szabad bővítményt kifejtők közé.

4. Hogy Brassai hány hosszadalmas lábjegyzetet írna a TNyt. koncepciójával, megoldásaival kapcsolatban? Nem tudhatjuk. Azt azonban igen, hogy több mint száz évvel ezelőtti müveinek hatása ma is eleven a magyar nyelvtudomány minden egyes ágában, még az általa nem sokra becsült történetiben is. Ha csupán az itt elhangzott előadások tematikáját vesszük sorra, saját hasonlatával azt mondhatjuk róla, hogy olyan mint a nap, akárhonnan nézzük, ránk (is) süt.

\footnotetext{
${ }^{87}$ Vö. StruktNyt. I, 595.
} 